\title{
NOMES QUE (DES)CONECTAM: GRAVIDEZ E PARENTESCO NO RIO DE JANEIRO*
}

\author{
Claudia Barcellos Rezende
}

Tatiane havia se formado há pouco tempo quando engravidou. Casada há dois anos, a gravidez não foi "nem planejada nem não planejada". Foi recebida com um misto de alegria e receio por parte de seu marido, que era técnico de informática e, "como todo pai", se preocupava com as condições financeiras de sustento da família. Como era o primeiro neto da família, estavam todos - pais, avós, irmão, sogros - muito entusiasmados. Tatiane gostaria de chamá-lo de Cassiano, um nome considerado antiquado e "feio" por muitos ao seu redor. Essas reações a aborreciam, mais do que os conselhos constantes sobre como se cuidar. Já em relação ao sobrenome, Tatiane disse escolher a tradição - passar ao filho tanto seu sobrenome quanto o do pai: Ferreira dos Santos. O sobrenome de sua mãe era Giuliani e era este que ela usava em seu perfil do Facebook. Apesar de considerá-lo "bonito e diferente", não achava correto passá-lo. Além de ser sobrenome de sua mãe - e a norma, ela frisou, era transmitir o de seu pai - era também o sobrenome de seus bisavós, descendentes de escravos, que haviam sido adotados pela família Giuliani, imigrantes italianos. Apesar de sua gratidão, não era uma relação de "sangue". As pessoas questionavam sua decisão, mas Tatiane reiterava que não era a "ordem da lei". ${ }^{1}$

Como Tatiane, as gestantes com quem conversei tinham muitas histórias para contar em torno dos nomes para o bebê que esperavam. Nomear o bebê antes de seu nascimento era uma prática comum e as mulheres buscavam explicar por que tinham escolhido certo nome ou sobrenome, ou por que ainda não o tinham feito. Estas histórias fazem parte de narrativas da gravidez que venho estudando nos últimos anos (Rezende 2011, 2012), buscando entender como a gestação do primeiro filho dá inicio à transformação da rede de parentesco (Duarte \& Gomes 2008), realçando, portanto, o caráter processual da relacionalidade (Carsten 2000). As mulheres e seus maridos estão assumindo novos papéis como mães e pais e têm várias decisões a tomar, entre elas a escolha do nome e dos sobrenomes da criança. Porque 
foi objeto de muito debate, neste artigo exploro o processo de decisão das gestantes e de seus maridos enquanto nomeadores. Revelava-se então o "peso ontológico" relativo (Pina-Cabral 2010a) de seus laços de parentesco, indicando que os vínculos ganhavam densidades existenciais distintas, de tal forma que certos sobrenomes eram passados e outros não. A combinação resultante criava relações em torno de redes específicas, ocultava outros laços e ao mesmo tempo diferenciava as gerações. Enquanto isso a condição de pessoa do bebê começava a ser elaborada e articulada com a socialidade, o que implicava desenvolver conexões e desconexões através dos nomes e dos sobrenomes.

Enquanto os nomes próprios são usualmente considerados instâncias de individuação, os sobrenomes são tomados como formas de inserir a pessoa em uma rede de relações sociais já existentes (Finch 2008). Mais ainda, do mesmo modo que outros nomes coletivos, os sobrenomes não apenas identificam uma pessoa como parte de uma rede, mas criam também essas relações. Neste sentido, como Bodenhorn e Vom Bruck (2006) e Iteanu (2006) destacam, há uma dimensão estratégica quanto ao processo de nomeação em termos das relações potencialmente estabelecidas. Wagley (1971), em sua leitura da sociedade brasileira da década de 1960, comentou brevemente como a transmissão de sobrenomes, especialmente os de elite, podia ser manipulada de forma a enfatizar laços com ancestrais importantes, particularmente aqueles com mais prestígio social. De fato, discuto nas narrativas analisadas aqui como a escolha de sobrenomes torna-se um modo de dar visibilidade a algumas relações enquanto obscurece outras. Mais ainda, argumento que em qualquer processo de nomeação há sempre vínculos sociais preteridos, enquanto outros são realçados ou criados. Deste modo, a escolha dos sobrenomes dos bebês esperados é uma forma de estabelecer a continuidade de certos laços de parentesco, ao mesmo tempo em que produz diferenciação entre as gerações ao retirar certas conexões dos nomes.

A possibilidade de escolher sobrenomes para o filho tem particularidades nas sociedades portuguesa e brasileira. Como Monteiro (2008) aponta, a prática atual de dar ao filho um sobrenome materno e outro paterno, nesta ordem, foi legalmente estabelecida em Portugal no início do século 20. No Brasil, regras em torno do sobrenome dos filhos foram criadas em 1939, sugerindo que a criança deveria ter um prenome e um nome de família. O Código Civil de 2002 mantém-se vago sobre a escolha dos sobrenomes, declarando apenas que cada pessoa tem direito a um nome composto pelo primeiro nome, ou nome próprio, e o sobrenome. Como Carvalho (2008) explica, nomes próprios e sobrenomes podem ser simples ou compostos e 
estes últimos podem vir das famílias materna, paterna ou de ambas. Pina Cabral e Viegas (2007) destacam que esta margem de escolha mais ampla é um traço do parentesco baseado na descendência bilateral presente em Portugal e no Brasil. A prática comum é dar à criança os sobrenomes tanto do pai quanto da mãe, mas as variações são igualmente comuns, como discuto neste artigo. Geralmente, o sobrenome de uma criança será igual ao de seus irmãos, filhos dos mesmos pais, mas será diferente das gerações precedentes. De um modo geral, os nomes uma vez registrados não podem ser modificados, embora seja possível que as mulheres, ao casarem, adicionem o sobrenome de seus maridos e/ou a Justiça estabeleça ou renegue paternidade através do sobrenome paterno, como apresentarei adiante.

Neste sentido, enfatizo o significado das práticas de nomeação para o parentesco, como fizeram Bodenhorn e Vom Bruck (2006) e Pina-Cabral (2013). A definição recente de Sahlins de parentesco enquanto "'mutualidade do ser': pessoas que são intrínsecas à existência umas das outras" (2011:02, minha tradução $\left.{ }^{2}\right)$ realça a dimensão intersubjetiva que é explicitada nos processos decisórios que examino. No entanto, sua abordagem tende a focalizar mais os aspectos positivos do parentesco, diminuindo o peso das dinâmicas de diferenciação que estão presentes no material discutido aqui. As práticas de nomeação podem ser um dos muitos elementos através dos quais a relacionalidade é constituída e negociada, revelando assim seus processos de "adensamento" ou "afinamento" através do tempo (Carsten 2000, 2013). A gestação e o nascimento de uma criança são momentos importantes do ciclo da vida que representam não apenas continuidade, mas também transformação de uma rede de relações (Carsten 2000:16).

Embora para as mulheres estudadas o parentesco fosse visto em larga medida como baseado em uma biologia "natural" e compartilhada, como em muitas sociedades ocidentais (Edwards \& Strathern 2000; Fonseca 2004; Ragoné 1997; Salem 1995; Schneider 1980), elas se preocupavam constantemente com a manutenção dessas relações, como evidenciado nos debates em torno dos sobrenomes dos filhos. Apesar de reconhecerem as práticas tradicionais de transmissão dos nomes, elas não as questionavam, e não as acionavam necessariamente. $O$ fato de os sobrenomes serem marcadores sociais, étnicos e, em alguns casos, religiosos, era igualmente significativo e afetava as escolhas a serem feitas.

Analiso as narrativas da gravidez a partir de uma perspectiva que toma a subjetividade como forma de pensar e sentir modelada culturalmente (Ortner 2006), revelando de maneira singular a articulação de elementos e laços sociais. Nesta abordagem, as emoções expressas são particularmente 
significativas, pois manifestam o estado afetivo de um sujeito em sua relação com o mundo e com os outros (LeBreton 2009) e afetam pragmaticamente o desenho e a dinâmica dessas relações (Abu-Lughod \& Lutz 1990). Foram realizadas 22 entrevistas com mulheres, complementadas com trabalho de campo em um grupo de gestantes. ${ }^{3}$ No grupo, observei várias discussões em torno de gravidez, parto e pós-parto que explicitam o modo de pensar o bebê e sua condição de pessoa. As entrevistas cobriram uma variedade mais ampla de temas, incluindo as relações com as famílias. Assim, a discussão específica sobre os nomes e os sobrenomes deriva deste material e vejo as narrativas das gestantes como reveladora de suas formas de pensar e produzir relacionalidade.

Em ambas as situações de pesquisa, as mulheres esperavam seus primeiros filhos, estavam casadas e tinham idades que variavam entre 28 e 35 anos. Destas, cinco eram negras, com visões que valorizavam uma identidade negra, e as demais se consideravam brancas. Todas tinham formação universitária, em áreas como engenharia, psicologia, geografia, economia, pedagogia e enfermagem, sendo que apenas seis tinham pais igualmente formados em curso universitário. Trabalhavam também em ocupações dos estratos médios. A maioria morava em imóvel próprio, todos passando por reforma ou mudanças para a chegada do bebê. Metade delas morava em bairros do subúrbio do Rio de Janeiro, como Bangu, Ricardo de Albuquerque e Campo Grande, com características socioeconômicas diversas, e o restante em bairros de classe média, como Tijuca, Leblon, Laranjeiras e Botafogo. Por fim, havia uma diversidade religiosa entre elas, sendo uma praticante de religião afro-brasileira, uma messiânica, cinco evangélicas, duas de ascendência judia e católica, e o resto católico, com graus variados de prática.

É importante destacar que todas mencionaram ter relações próximas com suas famílias de origem - pais, irmãos e tios - e por afinidade. Embora quatro delas tivessem pais morando em outra cidade, a maioria vivia em bairros próximos aos dos pais e tinha um convívio cotidiano frequente de se encontrar e falar várias vezes durante a semana, bem como tê-los acompanhando suas consultas e exames médicos. Seis mulheres tinham pais separados, alguns já casados pela segunda vez, e três tinham um dos pais falecidos. Ao contrário de gerações anteriores que buscavam uma ruptura de padrões em relação a seus pais (Almeida 1987; Salem 2007; Velho 1986), para estas mulheres, a família era uma referência importante, de valores e comportamentos a serem transmitidos. Ainda assim, veremos como as deliberações em torno do sobrenome do bebê apontavam para as várias nuances dessas relações, sugerindo uma forma contínua de atualizá-las. 


\section{Práticas de nomeação, relacionalidade e pessoa}

Em sua coletânea sobre a antropologia dos nomes, Bodenhorn e Vom Bruck (2006) argumentam que os nomes não apenas revelam noções de pessoa, como também participam de sua criação. Comentando dados etnográficos variados, as autoras propõem que os nomes sejam considerados coisas e que "o que os nomes são em um contexto particular está claramente conectado ao modo de pensar o que a nomeação como ato inicia" (2006:25). Humphrey (2006), por exemplo, discute a autoridade do sistema de nomes na Mongólia, onde os nomes são palavras que denotam qualidades que a criança deve ter. Em virtude de seu poder definidor, as pessoas evitam muitas vezes chamar os outros pelo nome pessoal, deixando assim espaço para que eles possam se apresentar com qualidades distintas daquelas evocadas pelo nome recebido.

Ao mesmo tempo, os nomes estão sempre articulados a relações sociais situadas no tempo, "historicizando" a pessoa de forma complexa e variada. Iteanu (2006) mostra como, para os Orokaiva, transmitir um nome prolonga-o no tempo para além da memória individual, designando assim genealogias que constroem uma história social fixa. Esses nomes coletivos pouco funcionam como forma de identificar características pessoais do sujeito, ao contrário das narrativas que discuto aqui e que buscam equilibrar pertencimento e diferenciação. O estudo de Layne (2006) com casais americanos de classe média com experiências de aborto involuntário é outro exemplo de como os nomes marcam a localização em uma geração de parentesco específica. A autora sugere que o ato de nomear o bebê nascido morto ajuda não apenas a lidar com sua morte, como também a construir a paternidade do casal. Nesse processo, os pais produzem então o nascimento social do bebê, dissociado de seu nascimento biológico.

Contudo, a articulação entre as práticas de nomeação, a condição de pessoa e as redes de relacionalidades é menos explorada. Os trabalhos de Pina Cabral (2010a, 2010b, 2013) formam uma exceção e são particularmente relevantes aqui por analisarem dados etnográficos brasileiros. Retomando a noção de Sahlins do parentesco como a mutualidade do ser, Pina Cabral relembra sua implicação para a pessoa, que sempre vem com uma pré-história. Neste sentido, nunca há um começo claro desse processo, uma vez que "as pessoas se veem ligadas de forma causal com pessoas que vieram antes" (2013:76). No entanto, a singularidade que existe na pessoa reside no fato de sua história de ontogenia pessoal ser sempre única; "nossos nomeadores são outros particulares e não um outro genérico" (2013:76).

Pina Cabral acrescenta que as pessoas lidam com seus passados de formas distintas, como parte de um processo de "copresença na constituição 
individual" (2013:76). Estas negociações seriam "identidades continuadas", que são fundamentalmente afetivas e em constante processo de atualização e revalidação. Os nomes seriam uma dessas instâncias de conexão com o passado da pessoa, pois eles evocam os nomeadores e suas intenções ao escolherem um nome, e assim se referem a uma "identidade continuada" com eles. Entretanto, argumento aqui que, quando as pessoas se tornam nomeadores, elas se veem na posição de decidir se projetam para o futuro, ou não, esta "identidade continuada" com o passado.

Nesse processo de evocação, Pina Cabral (2010a) fala de nomes que são mais verdadeiros do que outros. Referindo-se ao uso efetivo dos nomes, ele mostra como no mundo lusófono as pessoas podem ser chamadas de formas variadas - pelo primeiro nome, por um apelido, por um ou por todos os sobrenomes - mas elas tendem a considerar apenas um deles como o nome verdadeiro. Este revela o que tem peso ontológico para a pessoa - aquelas relações que têm mais significado ou existência do que outras. Acrescento que as negociações que as pessoas fazem com seus passados são afetadas pelos distintos pesos ontológicos de suas relações, bem como por seus projetos para o futuro.

Ao pensar a escolha dos nomes para a criança, o aspecto classificatório dos sobrenomes adquire relevância. Os sobrenomes classificam as pessoas em termos de pertencimento a redes de parentesco específicas, que são por sua vez socialmente localizadas. Assim, eles frequentemente indicam posições de classe, identidades religiosa, étnica ou identidade nacional. A dimensão da visibilidade da inserção social permitida pelos sobrenomes torna-se crucial, como Finch (2008) ressalta. Wagley, ao analisar famílias de elite brasileiras, comentou que os sobrenomes são "símbolos públicos de pertencimento a uma parentela ou a uma família com uma figura ancestral importante" (1971:170). Os sobrenomes podem revelar vínculo com minorias étnicas e, no caso de discriminação e perseguição, podem ser alterados, como aconteceu com os judeus em Portugal após a Inquisição. ${ }^{4}$

A importância da visibilidade de um sobrenome é particularmente acentuada quando as pessoas desejam estabelecer ou reivindicar laços de parentesco e os direitos que eles instituem. O estudo de Fonseca (2004) sobre processos de investigação de paternidade, com recurso a exames de DNA, em Porto Alegre, exemplifica esta questão. Fonseca argumenta como os exames de DNA contribuíram para dar mais significado a uma visão biológica da paternidade, que durante muitas gerações foi principalmente um laço social. Ainda é comum, especialmente nas camadas trabalhadoras, a prática da "adoção à brasileira", em que um homem assume o filho de sua atual companheira, registrando-o como filho, com seu sobrenome. Assim, 
para estes homens, a paternidade se estabelece através da relação conjugal, passando primeiramente pela relação do homem com a mãe da criança. Se a relação termina com suspeita de infidelidade da mulher e se exames de DNA comprovam a ausência de paternidade biológica, o laço do homem com a criança pode ser afetado a ponto de a paternidade ser revogada por lei e o sobrenome paterno ser retirado da certidão de nascimento.

A posição daqueles que dão o nome vem a ser, portanto, imbuída de responsabilidade moral, como Bodenhorn e Vom Bruck (2006) propõem. São eles que lidam com o passado para projetar o futuro, como fazem as mulheres que estudei e aquelas pesquisadas por Pina Cabral (2007), que davam aos filhos o mesmo nome dos pais ausentes na tentativa de fortalecer o laço entre pai e filho. São eles que decidem se adotarão critérios comuns, como a visão no Brasil de que os nomes devem ser marcados pelo gênero (Motta 2007), ou se afastarão destes, como o descendente de uma família de elite portuguesa que rompeu a tradição de gerações de dar o mesmo nome próprio ao filho (Lima 2007). É claro que a audiência é sempre parte do processo de nomeação, seja de forma explícita ou implícita, validando, criticando ou rejeitando os nomes dados (Rosaldo 1984), como na história de Tatiane, com a qual comecei este artigo.

\section{Escolhendo o nome do bebê}

A gravidez era, para as mulheres estudadas, vivida como um estágio inicial da maternidade, particularmente associada à percepção do bebê esperado como pessoa. ${ }^{5}$ Várias entrevistadas atribuíam ao bebê características subjetivas com base no modo como ele ou ela se movia dentro da barriga. Estes movimentos eram vistos como padrões de comportamento que revelavam o "temperamento" do bebê, bem como seus gostos, que deveriam ser respeitados. Assim, muitas mulheres falavam das mudanças em suas rotinas, em especial dos seus hábitos alimentares, não apenas para cuidar da saúde do bebê, mas também porque certos alimentos pareciam perturbá-lo. Estes traços não estavam diretamente associados ao gênero, embora houvesse a preocupação entre aquelas que esperavam meninos de que eles fossem ser muito agitados.

A nomeação do bebê antes de seu nascimento contribuía para sua percepção como pessoa. Com o surgimento das ultrassonografias, vários casais escolhiam o nome para a criança em torno do quarto mês de gestação, quando o sexo do bebê era apontado (Chazan 2007). ${ }^{6}$ Daquele momento em diante, o casal, a família e os amigos frequentemente passavam a se referir ao bebê 
pelo seu nome. Muitas vezes as roupinhas e outras partes do enxoval eram bordadas com seu nome pelas futuras avós ou outros parentes. Os convites para os chás de bebês eram em geral escritos como se fossem feitos pelo próprio bebê ("Venham para o meu chá de bebê"), e não pelos pais, e este evento se tornava uma prévia do que seria o primeiro aniversário da criança, com seu nome nas decorações e no bolo. Também era este nome que figurava nos cartões de agradecimento às visitas e pelos presentes recebidos por ocasião do seu nascimento no hospital. Nomear o bebê na gravidez tornou-se de tal forma uma norma a ponto de uma entrevistada com dificuldade de decidir o nome do filho, cujo parto estava próximo, ter sido chamada pela irmã de "mãe desnaturada". 7

Os nomes próprios eram em geral escolhidos pelo casal. O mais comum era a mulher ou o marido ter um nome que ele(a) já gostava e o outro concordar com a escolha. Alguns casais decidiam que se o bebê fosse menina, a mulher escolheria o nome e, se fosse menino, o homem decidiria. Em todos os casos, a mulher e o marido tinham que concordar sobre o nome da criança. ${ }^{8}$ Muitas vezes eles se esforçavam para assegurar que esta seria uma decisão só deles, sem interferência da família ou dos amigos. Em função disso, um casal contou a toda a família que só iria decidir o nome do bebê na hora do parto, com a justificativa de que ambos queriam ver a "cara" do bebê antes de escolher. Seria uma tentativa de evitar o que aconteceu com Tatiane, que escutou comentários críticos da família e dos amigos sobre o nome "antiquado" e "feio" que tinha escolhido.

Nos casos estudados, não havia regras sobre qual nome dar à criança, a não ser acompanhar o gênero. Deveria ser um nome do qual o casal gostasse. Em duas situações em que o bebê esperado era um menino, o casal considerou dar-lhe o mesmo nome do pai, embora as mulheres reclamassem que seus filhos iriam ser chamados de "Júnior", um nome que não os singularizava. Entre as entrevistadas evangélicas, os nomes bíblicos com significados religiosos eram os preferidos. Duas delas escolheram nomes religiosos que tinham relação com episódios marcantes de suas vidas. Apenas uma mulher resolveu dar ao bebê um nome da família, o de seu avô, como forma de homenagear uma pessoa especial para ela.

Havia aqui também a preocupação de encontrar o nome "certo" para a criança, um traço comentado por Bodenhorn e Vom Bruck (2006). Alguns casais preferiam esperar até o bebê nascer para ver que nome teria mais "a ver com a sua cara". Embora muitos já tivessem decidido o nome meses antes do parto, sua visão sobre o nome - bonito, doce, forte - buscava espelhar o comportamento do bebê dentro da barriga. Aparecia também a preocupação de que o nome estivesse de acordo com o gênero e as mulheres 
que esperavam meninos se preocupavam com um nome que fosse "bem masculino". Por fim, o primeiro nome deveria combinar com os sobrenomes. Aqui também havia uma questão de gênero - qual combinação de nome e sobrenome seria melhor para um menino, de forma a não afetar sua masculinidade. As mulheres também buscavam evitar sobrenomes longos, que pareciam antiquados ou associados a uma monarquia que não existia mais. Eles também seriam pouco práticos (não caberiam na linha de assinatura do cheque, como disse uma entrevistada) e, no cotidiano, as pessoas acabariam usando apenas um sobrenome.

Mas a escolha de sobrenomes apresentava outras considerações e era com frequência mais difícil que a seleção do primeiro nome. Enquanto a maioria destes já havia sido selecionada na época das entrevistas, muitos ainda não estavam decididos. Os sobrenomes não apenas remetiam a laços de parentesco, mas também tinham implicações sociais mais amplas, como discuto abaixo através das histórias de Laura, Marina e Lucimar.

\section{A morte de um sobrenome}

Então, o sobrenome é um... [risos] Tudo é um problema. O sobrenome é outro problema. Porque eu acho, não sei, ainda tô pensando, mas nós achamos, na verdade, eu e ele, que talvez o nome mais três sobrenomes fique muito grande, entendeu? E por causa da mãe ter separado do pai, ainda ter um problema... Tem pouco tempo que eles se separaram... Tem uns seis anos só... Eu tenho certeza que a mãe dele gostaria muito que levasse o sobrenome dela. Só que pra levar o sobrenome dela, o do pai dele... o da minha mãe eu não vou colocar, porque a família da minha mãe é muito grande, tem muita gente, então assim... porque a gente tá pensando muito nisso, né? O que é que vai perpetuar mais, entendeu? Tipo, para o sobrenome não morrer... O da família do meu pai, se eu não colocar na minha filha, com certeza eu vou ter problema, porque a família é muito pequena. A da minha mãe não. A da minha mãe é muito grande, tem vários netos e pessoas que tão nascendo com o sobrenome, então não tem problema. Então, o que a gente tinha pensado? Em colocar o nome Maria; Moretti, que é o meu, do meu pai; de Azevedo, que é o do pai dele. Que é o normal. Porque o normal é colocar o dos pais, né? Só que se a gente não colocar o Farias, que é o sobrenome da mãe dele, tipo, Maria Farias Moretti de Azevedo, eu tenho certeza que a mãe dele vai ficar extremamente sentida, porque a família da mãe dele é igual à família do meu pai: extremamente pequena. Entendeu? E o sobrenome tá meio que acabando... Então, eles vão ficar chateados. Mas, tipo assim, não definimos nada ainda. 
Em sua entrevista, Laura falou muito da gravidez comemorada com sua família e a de seu marido. Ambos engenheiros, estavam casados há três anos e planejaram a gravidez após uma longa viagem de férias. Mesmo com sua mãe morando no Espírito Santo, o sogro em Valença e a sogra no Rio, as conversas por telefone, os presentes, as visitas mostravam uma participação intensa. Em alguns momentos, Laura demonstrava sua preocupação em equilibrar a atenção dada a todos - sua mãe e os sogros, para não excluir ou diminuir a importância de ninguém. Como seu pai falecera quando ela era criança, Laura cresceu com sua avó paterna disputando atenção e cuidado com sua mãe. Mesmo adulta, sempre que voltava a Valença, ela tinha que dividir seu tempo para não deixar sua avó magoada. Do mesmo modo, quando ia visitar os avós de seu marido, tinha que cuidar para não chatear sua sogra, que se aborrecia facilmente se eles passassem mais tempo com os avós. Estas questões apareciam também no processo de escolha do sobrenome da filha.

As dúvidas de Laura expressavam alguns dilemas comuns a outras gestantes entrevistadas. Primeiro, destaca-se em seu depoimento a ideia de uma prática de nomeação "normal", que seria dar ao filho o sobrenome do pai de cada um dos cônjuges. Entretanto, com a frequência dos divórcios, filhos de pais separados começavam a questioná-la em função das relações mantidas com cada um dos pais após a separação. Para Laura, não dar a seu filho o sobrenome da sogra poderia chateá-la, como se houvesse uma tomada de lado na separação dos sogros. Demonstrar que não havia preferências era uma preocupação tanto de seu marido como filho quanto dela como nora. Embora os sogros participassem intensamente da gestação de formas variadas, a retirada de um sobrenome poderia ser vista como um agravo que ademais afetaria a visibilidade dos laços familiares entre o bebê e a família da avó paterna.

O segundo dilema para Laura era justamente manter vivos certos sobrenomes, de famílias pequenas, que podem "acabar", "morrer". Tanto a família de seu pai quanto a de sua sogra eram consideradas pequenas, com poucas pessoas nascendo, e a interrupção na transmissão dos sobrenomes era vista como "acabando" com eles. Além do mais, seu pai havia falecido e Laura tinha uma forte relação com sua avó paterna. Assim, passar o sobrenome do pai parecia não apenas manter "vivo" seu sobrenome, mas também o vínculo com sua família paterna após a sua morte.

Esta preocupação estava igualmente presente no relato de Júlia, cuja mãe era judia e vinha de uma família pequena. No seu caso, acrescentar este sobrenome ao nome da filha seria uma forma de dar continuidade não apenas àquele sobrenome, mas também revelar o fato de Julia se ver como judia, embora seu pai fosse católico. O sobrenome materno expressava assim sua 
identidade judia, que ela achava importante passar para a filha, mantendo também a tradição de fazer presente a identidade religiosa judia através das mulheres. Do contrário, sua filha só teria sobrenomes católicos - Assunção Batista. Assim, a escolha por transmitir um sobrenome materno, que "normalmente" não seria passado adiante, era uma tentativa de conservar tanto uma linhagem de parentesco quanto uma forma de pertencimento étnico.

Retornando a Laura, embora ela buscasse equilibrar a atenção dada às várias relações, em outro momento da entrevista ela se queixou da tensão no relacionamento com sua avó paterna e sua sogra. Falou dos problemas constantes ao visitá-las e dos comentários que sempre ouvia sobre o que eles deveriam ou não ter feito. Laura não sabia ao certo como descrevê-las pessoas ciumentas ou centralizadoras - mas este jeito de ser a incomodava muito. Talvez por causa desta tensão, na entrevista, quando Laura considerou dar à sua filha o sobrenome Farias de sua sogra, ela o separou do sobrenome do seu sogro, de Azevedo, e o colocou antes de Moretti, seu sobrenome paterno, criando assim uma ordem de nomes pouco usual, porém significativa.

Sobrenomes longos não eram apreciados, mas não eram tampouco desconsiderados. No final, Laura e seu marido decidiram manter todos satisfeitos e deram à filha três sobrenomes - Moretti Farias de Azevedo, agora na ordem mais comum em que os sobrenomes maternos precedem os paternos. Dada a crítica de Laura aos comportamentos individualistas, magoar a família por conta das preferências do casal não parecia ser uma opção, diferente do que Marina pensava, como mostro a seguir.

\section{A política dos nomes}

Marina esperava uma menina, que iria se chamar Sofia. Ela ponderava a respeito do sobrenome de Sofia:

[Ela vai ter] o meu sobrenome e o dele, um só. Aliás, isso foi uma coisa engraçada porque a mãe dele comentou isso, as famílias em São Paulo têm dois sobrenomes, a família deles é Dias Carneiro, e aí eu falei: olha, se tiver dois sobrenomes teus, vai ter que ter dois meus, não quero saber, aí ele fica com esse papo de.... É engraçado que são só nos homens que colocam dois, então é super machista... Todas as crianças têm três sobrenomes, dois do pai e um da mãe. Aí, eu falei: "mas aqui no Rio não é assim o sistema (risos), e eu não quero saber se o nome do pai é sobrenome duplo, se ela tiver dois seus, ela vai ter dois meus e acabou (risos). E aí vai ficar com o nome muito grande". Como ele usa Dias, a gente cortou o Carneiro, que é o último, mas foi o que ele preferiu. Aí, eu falei: “Bota o 
que você quiser, aí vai ficar Gonçalves, que é o meu, e Dias". Os pais dele ficaram indignados (risos): "Mas como assim vai cortar o nome, e a mãe dele: "não, mas tem que ter Carneiro", ficou revoltada. [...] Aí, eu falei: "Você tá brigando por um sobrenome que nem é o seu, se tivesse falando pelo seu... Mas você está brigando pelo do seu marido... E mais, você está querendo discutir com um casal que concorda". Se eu e Roberto tivéssemos alguma discordância, ela falava o que ela achava, tudo bem, mas a gente concordava. E aí ela ficou chocadíssima!

Marina era psicóloga social e muito envolvida com causas feministas. Ela e Roberto haviam se conhecido durante o doutorado e estavam muito contentes com o bebê, que seria o primeiro neto de suas famílias. Eles dividiam todas as tarefas domésticas e ela tinha muito apoio de sua família, que já se prontificava para ajudar nos cuidados com a neta. Esta era uma questão para ela, que se perguntava como seria a conciliação da maternidade, algo muito desejado, com sua carreira acadêmica, igualmente importante para ela.

Marina falava de sua mãe e sua sogra em termos de dois modelos de gênero distintos, o que explicava também o estado de suas relações. Sua mãe, professora universitária, politicamente de esquerda, era modelo para ela, que foi criada em uma relação de muita proximidade e muito diálogo, de sair para tomar cerveja com ela e seus amigos. A sogra, por sua vez, vinha de uma família conservadora de uma cidade pequena do interior de São Paulo. Embora tenha trabalhado quando jovem, aposentou-se cedo e tornou-se dona de casa. A relação com a sogra era tensa, com alguns embates em torno de como ela deveria gerir a casa, a vida do filho e, agora, a chegada da neta Sofia. Nas palavras de Marina, a sogra devia achá-la "mega individualista" por dividir as tarefas domésticas com o marido e trabalhar o dia inteiro, cuidando "menos" da casa e da família.

Não à toa, as decisões em torno do sobrenome da filha espelhavam essas tensões. A escolha do casal de dar a ela um sobrenome de cada um chocava a sogra, pois implicava "cortar" um sobrenome duplo, visto como tradicional na sociedade paulistana. Marina não valorizava esta tradição e buscava ativamente se contrapor a ela. Para ela, os sobrenomes duplos paulistanos, que identificavam famílias de elite há muitas gerações, vinham associados a uma visão tradicional de família, com uma divisão de trabalho de gênero assimétrica que a revoltava. O próprio fato de que os pais davam aos filhos dois sobrenomes, enquanto as mães transmitiam apenas um indignava-a. Assim, o sobrenome de sua filha deveria demonstrar sua inserção em duas famílias de uma perspectiva feminista igualitária. Seria um sobrenome de cada um, como eles escolheram, ou o sobrenome composto de Roberto e seus dois sobrenomes, o que resultaria em um sobrenome longo. 
Marina também mencionou o fato de que mesmo Roberto não usava seu sobrenome composto habitualmente, isto é, apesar dos sobrenomes recebidos de seus pais, no seu cotidiano ele escolhia como queria se apresentar. Talvez por ele também ter convicções políticas de esquerda, parecia preferir não ser identificado com uma família conservadora "tradicional". Como Rosaldo (1984) enfatizou, os atributos dos nomes se referem inicialmente àqueles que dão os nomes, no caso, os pais de Roberto.

Na narrativa de Marina, as discussões sobre os sobrenomes revelavam tensões nas relações de afinidade, baseadas em perspectivas distintas sobre os papéis de gênero e na importância da classe social. Do ponto de vista de sua sogra, a postura feminista de Marina significava cuidar menos de seu marido e de sua casa (e talvez de sua neta no futuro), não desempenhando, portanto, os papéis femininos tradicionais, e também desconsiderava a posição social da família de Roberto, espelhada no sobrenome composto. Dias Carneiro era um sobrenome que identificava uma longa linhagem de elite. Passar apenas um dos sobrenomes criava uma forma de identificação diferente, que era exatamente o que Marina desejava e o que o casal resolveu fazer.

\section{A feiúra de um sobrenome}

Lucimar esperava um menino que ainda não tinha nome. Ela explicou:

“[Ele] não tem nome ainda porque o pai ainda tá orando pra vir um nome do céu, ele vai vir do céu mesmo, porque eu já tô quase ganhando e ele ainda não decidiu. [...] Já, então, o sobrenome tá uma política, porque na verdade, o sobrenome seria Da Silva Nogueira, só que o meu marido tá tão empolgado com a criança que ele quer colocar só o sobrenome dele, ou seja, ele quer me excluir... (risos) [...] O meu é Da Silva e o dele Nogueira. Então, ele fala assim: "Deixa só o meu nome, porque o seu nome Da Silva é muito feio, é muito nome de pobre!". Eu falei: “Não, vai ficar o meu nome e o seu!", e ele: “Não, meu filho vai ter que ter só o meu nome!" [...] Então, ele está tão empolgado que ele acha que por eu já estar carregando o neném, de eu ter esse privilégio, pelo menos o nome tem que ser o dele, porque o privilégio todo tem que ser dele só no nome. [...] Aí eu falei: não! Tá num impasse! A gente às vezes ri da história, às vezes eu me aborreço, às vezes eu rio também porque eu chego a achar engraçado, cômico, né? Ele não querer deixar o meu nome, meu sobrenome, querer deixar só o sobrenome dele! Mas enfim... mas isso eu tenho certeza que depois a gente se entende, até o final, até nascer, pois é óbvio que eu não vou permitir isso: ficar só o sobrenome dele seria até egoísmo da parte dele. 
Lucimar era enfermeira e já estava casada há oito anos quando engravidou. Daniel, seu marido, trabalhava como gerente de restaurante e ainda achava que eles podiam esperar mais para ter um filho, para que tivessem melhores condições financeiras e terminassem de construir sua casa. Mas como mulher - "e a mulher sempre acaba decidindo isso" - ela se programou para engravidar e fazer uma surpresa para ele. Apesar do susto inicial, Daniel estava muito entusiasmado com a gravidez. Embora houvesse outros netos, sua família estava muito alegre com o bebê, que já era um "pouquinho filho" da irmã e da cunhada, do mesmo modo que ela era muito "tiazona". A família de Roberto gostou também "da ideia", apesar de eles serem mais distantes.

As discussões em torno de que sobrenome dar ao filho mostram também os embates entre os cônjuges e as diferenças familiares. Se Lucimar havia decidido sozinha engravidar quando Daniel ainda não estava pronto, agora era ele quem queria escolher sozinho o nome e o sobrenome do filho. O nome seria de inspiração divina, que ainda não havia vindo até ele. O sobrenome seria só o dele. Apesar de menos comum entre as entrevistadas, havia duas mulheres cujos filhos homens não teriam seu sobrenome, uma vez que herdariam todo o nome do pai já transmitido há duas gerações, acrescido de "Filho" ou "Neto" ao final, prática que também reforçava a identificação entre pais e filhos, como aponta Pina Cabral (2007). Mas no caso de Lucimar, o bebê não se chamaria Daniel, pelo menos não na época da entrevista.

Esta disputa expressava não apenas negociações de poder entre o casal, mas também ideias diferentes sobre os laços entre pais e filhos. Assim, o vínculo de Lucimar com o bebê seria criado pela gestação, e era considerado um "privilégio" que os homens não tinham. Como era um laço biológico, não precisaria se fazer presente no sobrenome, na visão de Daniel. Nesta perspectiva, o modo de os pais estabelecerem suas relações com os filhos passaria principalmente por registrá-los com seu sobrenome. Relembrando o estudo de Fonseca (2004), a paternidade para as pessoas de camadas trabalhadoras que ela pesquisou era reconhecida e demonstrada através do registro na certidão de nascimento de uma criança com o sobrenome do pai. O significado do sobrenome paterno aparecia em especial naqueles casos em que estava ausente. Embora nas últimas décadas muitas mulheres venham sustentando suas casas, o papel de provedor ainda é um traço masculino importante, e ter um pai na certidão de nascimento representa simbolicamente poder prover os filhos.

Há uma terceira dimensão nas negociações de Lucimar e Daniel em torno do sobrenome do filho, que é ao mesmo tempo estética e social. "Da Silva", nas palavras do marido, é nome de pobre e é "muito feio". O próprio nome de Lucimar resultava de uma prática de combinar partes dos 
nomes dos pais, comum nas camadas trabalhadoras. Um sobrenome que marcava uma origem social pobre parecia ser problemático para Daniel, que tinha ascendência turca e vinha de uma família com projetos de ascensão social. Embora Lucimar não tivesse falado de origens sociais distintas, a família de Daniel tinha outra "cultura", todos muito voltados para eles mesmos, cada um por si. Sua sogra era evangélica, mas estava "desviada"; seu sogro era católico, mas não era praticante. Sua família, ao contrário, era muito unida. Se ela passasse mal, todos apareceriam juntos na porta do hospital para saber o que tinha acontecido. Nas palavras dela, "a minha família é muito família mesmo [...] é assim uma bênção de Deus, todo mundo é muito unido, todo mundo vive os problemas de todo mundo e as alegrias de todo mundo". Assim, o desejo de Daniel de dar ao filho apenas seu sobrenome tornava-se, para Lucimar, um desejo "egoísta", uma acusação moral explicada pela diferença dos valores familiares. A disputa em torno dos sobrenomes expressava as tensões do casal em torno da mobilidade social, que nas camadas trabalhadoras aparecia, com frequência, como um afastamento da identidade holista dada pela rede familiar através da adoção de valores individualistas (Duarte \& Gomes 2008).

Lucimar aguentou o suspense até o momento do parto, temendo que Daniel aparecesse com um nome "feio". Somente no hospital ele contou para ela que Deus havia escolhido Samuel, nome de que ela gostou. Já como sobrenome, ele conseguiu deixar de fora o "Da Silva", dando ao filho outro sobrenome materno mais inconspícuo, Campos, e seus dois sobrenomes, Nogueira Akalin.

\section{Sobrenomes e sentimentos}

Estas histórias revelam como o processo de escolha de nomes e sobrenomes é específico das vivências subjetivas dessas mulheres, de suas relações conjugais e redes familiares e, ao mesmo tempo, marcado por práticas de nomeação recorrentes, concepções culturais de pessoa e gênero, valores familiares e posição social. A preocupação de Laura com sua sogra contrastava com a postura de Marina de confrontar a sua. Tatiane valorizava a "ordem da lei", apesar da tentação de dar ao seu bebê o sobrenome italiano de seus antepassados adotivos, enquanto Lucimar tinha que negociar com seu marido a transmissão de seu sobrenome "feio". Em cada situação, o contorno da rede familiar e o estado das relações eram distintos.

Apesar das singularidades destas histórias, há claras regularidades entre elas, aspectos presentes também nas narrativas das outras mulheres 
estudadas. Em todas elas os nomes estabeleciam a condição de pessoa e as conexões sociais do bebê esperado. Os bebês eram vistos como seres dotados de agência e seus nomes próprios tornavam-se elementos importantes de suas subjetividades imaginadas, uma vez que eles deveriam refletir certo tipo de temperamento a ser revelado na "sua cara". Os nomes também construíam uma pessoa marcada pelo gênero, pois eles não apenas indicavam um gênero, como também eram escolhidos com base em modelos de feminilidade e masculinidade. Como no estudo de Layne (2006), os nomes contribuíam para o nascimento social da criança bem antes de seu nascimento biológico. Não era uma identidade fixa, pois um menino esperado poderia vir a ser uma menina, como aconteceu com Tatiane, que deu à luz a Andressa e não a Cassiano. Mas a nomeação dos bebês ajudava os futuros pais a se relacionarem com eles como pessoas, que se tornavam filhos antes de nascer, inserindo-os assim em uma rede de laços afetivos.

Se os nomes próprios eram normalmente escolhidos pelo casal somente em termos de seus gostos e preferências, a decisão em torno dos sobrenomes sempre implicava a rede de parentesco mais ampla e as conexões a serem tornadas visíveis ou obscurecidas. Aqui está outra instância daquilo que Pina Cabral (2013) denominou de negociação com o passado, ao mesmo tempo em que se engajava com o futuro: ao fazer a escolha do que passar para a criança, os casais avaliavam o significado de cada sobrenome para eles e as consequências desta seleção. Todas as mulheres se referiram ao costume comum de dar o sobrenome paterno de mãe e pai, o que implicava deixar para trás os sobrenomes maternos. Se para alguns era mais fácil seguir a prática usual, a ideia de que as futuras avós aceitariam pacificamente a não transmissão de seus sobrenomes deixou de ser fato. Com isso, várias mulheres ponderavam não seguir a "tradição", sempre em função do estado afetivo de suas relações de parentesco e de seus pesos ontológicos distintos.

Além disso, a decisão de dar um sobrenome específico à criança não era apenas um modo de localizá-la em uma rede de relações. Os sobrenomes também expressavam pertencimento étnico e posições de classe. Para alguns, seus projetos de ascensão social poderiam ser maculados pela transmissão de um sobrenome "de pobre" de um dos ramos da família. Para outros, convicções políticas de esquerda poderiam fazê-los recusar sobrenomes compostos associados à elite. Portanto, a qualificação de sobrenomes como "feios" e "bonitos" expressava a transposição de posições de classe para valores estéticos, de forma que a decisão de "cortar" um sobrenome nestas bases modificava o estado das relações familiares. A escolha dos sobrenomes aparecia assim associada aos projetos para as gerações futuras, afetando e efetivando relações e posições sociais (Bodenhorn \& Vom Bruck 2006; Pina 
Cabral \& Viegas 2007; Wagley 1971). O conjunto de sobrenomes selecionado era sempre um meio de "adensar" ou "afinar" as relacionalidades, produzindo continuidade e diferenciação ao mesmo tempo.

O fato de os sobrenomes construírem conexões ou possíveis desconexões era particularmente evidente nas reações emocionais ao processo. As histórias apresentadas aqui indicam que o assunto é delicado, como atestam as várias menções das mulheres aos sentimentos de angústia, raiva, perplexidade e às dúvidas em torno da escolha a ser feita. De forma semelhante, esperava-se que os pais cujos sobrenomes não seriam passados aos netos ficassem "extremamente magoados", "chateados", "indignados" e "chocados". Todos estes sentimentos apontam para uma experiência de raiva, de emoção que geralmente se refere à quebra de regras morais (Lutz 1988). Dar um sobrenome a uma criança é um modo de conectá-la a uma rede familiar, de forma que não dá-lo torna-se um modo de desconsiderar as relações familiares, com a ameaça potencial de uma desconexão. Era, portanto, uma afronta moral e aqueles que a cometiam podiam ser acusados de "egoístas" e "vaidosos".

Por fim, o ato de nomear os bebês antes de eles nascerem produzia um trabalho temporal significativo de articular passado, presente e futuro. Os sobrenomes traziam consigo histórias familiares - como a adoção dos bisavós de Tatiane e a ancestralidade judaica de Julia — que corriam o risco de se perder, de modo que questões de continuidade e mudança afloravam. Neste sentido, a escolha de passar um sobrenome que estava "morrendo" poderia resgatá-lo de seu desaparecimento e reconstruir laços com ele. Ademais, ao nomearem um bebê esperado de acordo com o gênero e seus movimentos dentro da "barriga", os casais não estavam apenas imaginando seus filhos; estavam ativamente criando-os como pessoas. Ao anteciparem seu nascimento social, o casal - a mulher, em particular - antecipava também a paternidade e a maternidade. A nomeação tornava-se, portanto, um modo de trazer o passado e o futuro para o presente. Era uma forma de inserir o bebê esperado em histórias socialmente significativas, ao mesmo tempo enfatizando continuidades e produzindo diferenças entre as gerações.

Recebido em 11 de junho de 2015

Aprovado em 21 de setembro de 2015

Claudia Barcellos Rezende é professora associada do Departamento de Antropologia da Universidade do Estado do Rio de Janeiro (UERJ). Email: <cbrezende@bighost.com.br> 


\section{Notas}

* Os dados analisados aqui resultam da pesquisa "Pertencimento e parentesco na gravidez", apoiada pelo Programa Prociência da UERJ, pelo CNPq (Bolsa de Produtividade) e pela Capes (Bolsa Estágio Sênior). Priscilla Silva, Thales Moraes e Bruno Hammes participaram como assistentes de pesquisa. Uma primeira versão deste artigo foi apresentada na série de seminários do Departamento de Antropologia da Universidade de Edimburgo, em janeiro de 2014, durante meu período de pós-doutorado nesta instituição. Agradeço os comentários de Janet Carsten, Mark Harris, Jacob Copeman e Michele Wisdahl.

${ }^{1}$ Todos os nomes e sobrenomes utilizados foram trocados para manter o anonimato das pessoas estudadas. Procurei, contudo, escolher nomes de um repertório mantendo as características sociais discutidas aqui. Mantive apenas o sobrenome Da Silva, por ser icônico de um certo segmento social e ao mesmo tempo comum o suficiente para de fato identificar alguém.

${ }^{2}$ Todas as citações de textos em inglês são traduções minhas.

${ }^{3}$ Enquanto o trabalho de campo no grupo de gestante foi feito por mim durante quatro meses em 2008, as entrevistas foram realizadas juntamente com os assistentes de pesquisa. As diferenças de gênero da equipe não interferiram na maior ou menor elaboração dos relatos.

${ }^{4}$ Brink-Danaan (2010) mostra como os nomes próprios judaicos foram alterados ao longo da história para evitar perseguição. Em outra linha, Copeman (2015) discute como ateus indianos mudam seus nomes e mesmo sobrenomes relacionados a castas para nomes neutros ou de castas distintas, como forma de subverter as fronteiras entre elas.

${ }^{5}$ Esta percepção da gestação como etapa inicial da maternidade já aparecia em gerações mais velhas, como apontou Lo Bianco (1985) na década de 80. De forma semelhante, a visão do feto como pessoa está presente em formas mais disseminadas de pensar analisadas por Salem (1997).

${ }^{6}$ Chazan (2007) descreve várias sessões de ultrassonografia nas quais vários membros da família acompanhavam a gestante, já se relacionando com o bebê como membro da família.

${ }^{7}$ Robles (2015), em seu estudo com jovens gestantes em uma maternidade pública em Recife, explica que a falta de nome para os bebês esperados era entendida pela equipe médica como rejeição à criança.

${ }^{8}$ No estudo de Pina Cabral (2007), as mulheres eram as principais responsáveis pela escolha do nome da criança. 


\section{Referências bibliográficas}

ABU-LUGHOD, Lila \& LUTZ, Catherine. 1990. "Introduction". In: __ (orgs.), Language and the politics of emotion. Cambridge: Cambridge University Press. pp. 1-23.

ALMEIDA, Maria Isabel Mendes de. 1987. Maternidade, um destino inevitável? Rio de Janeiro: Campus.

BODENHORN, Barbara \& BRUCK, Gabrielle vom. 2006. '“Entangled in histories': an introduction to the anthropology of names and naming". In: __. (orgs.), The anthropology of names and naming. Cambridge: Cambridge University Press. pp. 1-30.

BRINK-DANAN, M. 2010. "Names that show time: Turkish Jews as 'strangers' and the semiotics of reclassification". American Anthropologist, 112:384-396. CARSTEN, Janet. 2000. "Introduction: cultures of relatedness". In: J. Carsten (org.), Cultures of relatedness. Cambridge: Cambridge University Press. pp. 1-37.

. 2013. "What kinship does - and how". HAU: Journal of Ethnographic Theory, 3(2):245-51.

CARVALHO, André Ricardo Fonseca. 2008. "Aspectos relevantes do nome civil". Revista Jus Navingandi. Disponível em: http://jus.com.br/revista/ texto/11782/aspectos-relevantes-do-nome-civil. Acesso em: 14/05/2013.

CHAZAN, Lilian Krakowski. 2007. Meio quilo de gente: um estudo antropológico sobre ultrassom obstétrico. Rio de Janeiro: Editora Fiocruz.

COPEMAN, Jacob. 2015. "Secularism's names: commitment to confusion and the pedagogy of the name". South Asia Multidisciplinary Academic Journal, 12. Dsponível em: http://samaj.revues. org/4012. Acesso em 12/11/2015.
DUARTE, Luiz Fernando Dias \& GOMES, Edlaine de Campos. 2008. Três famílias: identidades e trajetórias transgeracionais nas classes populares. Rio de Janeiro: FGV/Finep/CNPq.

EDWARDS, Jeanette \& STRATHERN, Marilyn. 2000. "Including our own". In: J. Carsten (org.), Cultures of relatedness. Cambridge: Cambridge University Press. pp. 149-166.

FINCH, Janet. 2008. "Naming names: kinship, individuality and personal names". Sociology, 42(4):709-725.

FONSECA, Claudia. 2004. "A certeza que pariu a dúvida: paternidade e DNA". Revista Estudos Feministas, 12(2): 13-34.

HUMPHREY, Caroline. 2006. "On being named and not named: authority, persons, and their names in Mongolia". In: G. Bruck \& B. Bodenhorn (orgs.), The anthropology of names and naming. Cambridge: Cambridge University Press. pp. 157-176.

ITEANU, André. 2006. "Why the dead do not bear names: the Orokaiva name system". In: G. Bruck \& B. Bodenhorn (orgs.), The anthropology of names and naming. Cambridge: Cambridge University Press. pp. 51-72.

LAYNE, Linda. 2006. "'Your child deserves a name': possessive individualism and the politics of memory in pregnancy loss". In: G. Bruck \& B. Bodenhorn (orgs.), The anthropology of names and naming. Cambridge: Cambridge University Press. pp. 31-50.

LEBRETON, David. 2009. As paixões ordinárias. Trad. L. Peretti. Petrópolis: Vozes.

LIMA, Antonia Pedroso de. 2007. "Intencionalidade, afecto e distinção: as escolhas de nomes em famílias de elite de Lisboa". In: J. Pina Cabral \& 
S. M. Viegas (orgs.), Nomes: gênero, etnicidade e família. Coimbra: Almedina. pp. 39-61.

LOBIANCO, Anna Carolina. 1985. "A psicologização do feto". In: S. Figueira (org.), Cultura da psicanálise. São Paulo: Brasiliense. pp. 94-115.

LUTZ, Catherine. 1988. Unnatural emotions. Chicago: University of Chicago Press. MONTEIRO, Nuno Gonçalo. 2008. "Os nomes de família em Portugal: uma breve perspectiva histórica". Etnográfica, 12(1):45-58.

MOTTA, Flavia Mattos. 2007. "'Em nome do pai e em nome da mãe': gênero e significado no estudo dos nomes". In: J. Pina Cabral \& S. M. Viegas (orgs.), Nomes: gênero, etnicidade e família. Coimbra: Almedina. pp. 121-143.

PINA CABRAL, João de. 2007. "Mães, pais e nomes no baixo sul (Bahia, Brasil)". In: J. Pina Cabral \& S. M. Viegas (orgs.), Nomes: gênero, etnicidade e família. Coimbra: Almedina. pp. 63-88.

_.2010a. "The truth of personal names". Journal of the Royal Anthropological Institute, 16:297-312.

- 2010b. "Xará: namesakes in Southern Mozambique and Bahia (Brazil)". Ethnos, 75:323-345.

. 2013. "The core of affects: namer and named in Bahia (Brazil)". Journal of the Royal Anthropological Institute, 19:75-101.

PINA CABRAL, João de \& VIEGAS, Susana de Matos. 2007. "Nomes e ética: uma introdução ao debate". In: __ (orgs.), Nomes: gênero, etnicidade e família. Coimbra: Almedina. pp. 13-37.

ORTNER, Sherry. 2006. Anthropology and social theory: culture, power and the acting subject. Durham: Duke University Press.

RAGONÉ, Helena. 1997. "Chasing the blood tie: surrogate mothers, adoptive mothers and fathers". In: L. Lamphere; H. Ragoné \& P. Zavella (orgs.),
Situated lives: gender and culture in everyday life. London: Routledge. pp. 110-127.

REZENDE, Claudia Barcellos. 2011. "The experience of pregnancy: subjectivity and social relations". Vibrant, 8:529-549. . 2012. "Em torno da ansiedade: subjetividade, mudança e gravidez". Interseções, 14(2):438-454.

ROBLES, Alfonsina Faya. 2015. "Regulações do corpo e da parentalidade durante o pré-natal em mulheres jovens de camadas populares". Civitas, 15(2):190-213.

ROSALDO, Renato. 1984. "Ilongot naming: the play of associations". In: E. Tooker (org.), In Naming systems: 1980 Proceedings of the American Ethnological Society. Washington: The American Ethnological Society. pp. 11-24.

SAHLINS, M. 2011. "What kinship is" (part one). Journal of the Royal Anthropological Institute, 17:2-19.

SALEM, Tânia. 1995. "O princípio do anonimato na inseminação artificial com doador (IAD): das tensões entre natureza e cultura". Physis, 5(1):33-68. - 1997. "As novas tecnologias reprodutivas: o estatuto do embrião e a noção de pessoa". Mana. Estudos de Antropologia Social, 3(1):75-94. -2007. O casal grávido: disposições e dilemas da parceria igualitária. Rio de Janeiro: Ed. FGV.

SCHNEIDER, David. 1980. American kinship: a cultural account. 2. ed. Chicago: The University of Chicago Press.

VELHO, Gilberto. 1981. Individualismo e cultura: notas para uma antropologia da sociedade contemporânea. Rio de Janeiro: Jorge Zahar. - 1986. Subjetividade e sociedade: uma experiência de geração. Rio de Janeiro: Jorge Zahar.

WAGLEY, Charles. 1971. An introduction to Brazil. Revised edition. New York and London: Columbia University Press. 
Resumo

Este artigo analisa como os sobrenomes estabelecem e afetam a relacionalidade do ponto de vista daqueles que nomeiam, no caso, gestantes de camadas médias do Rio de Janeiro. Explora, de forma específica, os processos decisórios das mulheres em torno da escolha dos sobrenomes para a criança esperada, na medida em que na sociedade brasileira uma pessoa tem geralmente sobrenomes das famílias materna e paterna. A escolha do sobrenome revela não apenas o estado afetivo dos laços de parentesco, mas também sua relação com identidades étnicas e posições sociais particulares. Cria, além disso, continuidade e descontinuidade entre gerações, uma vez que estes vínculos são avaliados em termos do desejo de expô-los ou torná-los obscuros. Assim, a inserção social da criança já começa a ser feita antes do seu nascimento, revelando também uma condição de pessoa já em processo de construção e de articulação com a socialidade.

Palavras-chave Relacionalidade, Nomeação, Pessoa, Gestação, Rio de Janeiro.
Abstract

This paper analyses the role of surnames in creating and affecting relatedness, seen from the perspective of namers, in this case middle-class pregnant women in Rio de Janeiro, Brazil. In particular, it explores women's decision-making process regarding which surnames to pass on to the expected child, given that in Brazilian society a person usually has surnames from both maternal and paternal families. Choosing surnames reveals not only the affective state of kinship ties, but also their relation to particular ethnic identities and social positions, and creates both continuity and differentiation between generations. In the selection process, connections are evaluated to be maintained and displayed or made obscure in the consciously constructed social insertion of the unborn child, whose personhood is already in creation and articulated to sociality.

Key words Relatedness, Naming, Personhood, Pregnancy, Rio de Janeiro. 